\title{
AFRICA: A POLITICAL ECONOMY OF CONTINUED CRISIS
}

\author{
Ray Bush \\ School of Politics and International Studies, University of Leeds, United Kingdom \\ This article deepens critique of the Africa rising trope and the policies promoted by neo liberals to \\ promote development on the continent. It revisits the economic growth literature and it shows how \\ the weakly formulated views about African growth are merely self serving of limited, mostly western, \\ investment interests that remain centred on extractive economies rather than helping to promote \\ sustainable structural transformation with added value that can be retained in Africa. There have \\ always been periods of economic growth in Africa but opportunities for this to be sustained do not \\ lie with greater integration with the world economy. Instead they lie with, among other things, local \\ political and economic struggles in Africa for greater democratic control of capital accumulation. \\ KEYWORDS: AFRICA; POVERTY; UNDERDEVELOPMENT; INDUSTRIALISATION
}

\section{Introduction}

This article develops the argument of my Annual Distinguished Lecture delivered at the 6th Ghent Africa Platform Symposium (GAPSYM6) at Ghent University on 7 December 20I2. That was subsequently published (Bush 2013) and the themes that I raised then are more pertinent than ever. The conditions of Africa's dependence on mining and extractives, for instance, escalating debt, being undermined by disadvantageous trade regimes and the continent's continued need to deal with the deleterious consequences of financialisation and the absence of effective industrial strategies have all intensified. Western policy towards Africa, the consequences of existing globalisation, persistently promotes what elsewhere in relation to development policy and practice has been called an elite subject - subordinate object relationship (Selwyn 20I6). Donor and international financial institution (IFI) relations with African governments are epitomised by the hegemony of an 'anti-poverty consensus'. That involves a doublespeak: donors and IFIs promote a development mantra that growth promotes the route to poverty reduction and so too does greater incorporation into the world economy (Selwyn 2017,2). Evidence that I assemble here, however, indicates the opposite. I highlight how Africa's (uneven) incorporation into the world economy continues to impoverish the majority of Africans. This is an argument that has been made in relation to the Africa rising debate (see among others Taylor 20I6). While reinforcing the critical debate about the persistently spurious argument that Africa is rising, I also indicate that there is worker and peasant opposition to donors and the IFIs, albeit that it may be partial and uneven. I stress the need for an historical 
understanding of African underdevelopment and the need for a context for understanding the ways in which radical African interventions are made within and from outside Africa. One of my critiques of existing policy-making about Africa, and from within the continent, is that it fails to unpack the dynamics of uneven development on the continent. In 2012 I was struck by some of the comments I received from the well informed audience in Ghent and a more detailed dialogue I had with a young participant. The audience responses were along the continuum of on the one hand, 'of course Africa is rising', 'just look at the continental growth rates' and why was I such a curmudgeon? On the other hand were the engaged observers who clearly knew not only the literature that I referred to but had empirical experience in Africa: they concurred with my analysis. The thoughts of the young activist who engaged with me were similar to the latter perspective; they already had African work experience and were angered and irritated by the imagery, and presented economic data, that Africa was progressing at a rapid pace. They were also critical of the idea that there was a singular path to development, and while Africa was on this path it was still a long way behind Europe and the US. But this activist had another line of interrogation which I had to stop and think about. How had it been possible to convince my peers over time for me to receive the title and rank of full professor despite my radical Marxist analysis? Moreover, wasn't it simply fantastic that the University of Ghent had been courageous to invite me and give a critical platform about African development, or the lack of it?

This conversation was important, not to glory in self-righteousness but to help reflect the struggles of radical Africanist scholarship, battles in Africa by activists, workers and peasants to promote alternatives to neo-liberal hegemony. It is often easier to cite examples of working class resistance to IFI and African government market led reforms. Egypt, Burkina Faso, and Tunisia are among the most recent and pressing examples (Beinin 2016; Chouli 2015). But Egypt and Tunisia also highlight the significance of rural resistance and organisation where peasant struggles over dispossession, land and irrigation access as well as merchant profiteering highlight activist battles for economic as well as political alternatives (Ayeb and Bush 20I4). But the challenge I am addressing is not only to assemble more data on examples of Africa's impoverishment, yet another critique of the Africa rising debate or to highlight working class and peasant reisistance. All that remains important as the tropes about the benefits of existing globalisation remain. But I also want to highlight the role of the western academic activist, what we might understand by a radical Africanist perspective in understanding the contemporary period and how difficult it is to promote alternative ideas in the world of academic publishing. A radical Africanist position is best introduced by referring to the editorial in the first issue of the Review of African Political Economy (I974). That journal began its life;

'with the express intent of providing a counterwieight to that mass of literature on Africa which holds: that Africa's continuing chronic poverty is primarily an internal problem and not a product of her colonial history and her present dependence; that the successful attraction of foreign capital and the consequent production within the confines of the international market will bring development; and that the major 
role in achieving development must be played by western-educated, 'modernising' elites who will bring progress to the 'backward' masses' (ROAPE I974, I)

The journal did not offer then, nor has it done so subsequently, a particular dogmatic line. It nevetheless recognised that 'Ultimately the specific answers will emerge from the actual struggles of the African people, on the continent and throughout the world' (ROAPE I974,2). While no blueprint was offered, the radical Africanist position is broadly Marxist. Analyses conducted by radical Africanists are aimed at promoting socialism: they is anti capitalist (Amin 2017). The approach is to explore changing and different patterns of production that hold the key to societal relationships, to analyse changing relations of production and the 'role of state power in reproducing them in order to identify the emerging contradications' (ROAPE I974: 2). Social relationships and especially class relations help explain the particular form that capitalism takes in Africa and the ways in which working class, peasant and other forms of struggle emerge to challenge established patterns of power and authority (for similar radical analyse see also www. Pambazuka.org and www.ROAPE.net).

For too long the work of radical Africanists has been characterised as just not academic enough and not fit for submission to the audit culture that has taken hold of Higher Education, certainly in the UK. University School research directors have become only interested in outputs perceived to be placed in 'world leading journals' where there is less likely to be a critique of the status quo, and thus also of government and policy- maker funding opportunities. That is particularly so in the discipline of economics where there is an overwhelming pressure for academics to fit their work into the dominant trends in academic disciplines, not least as a vehicle to secure research funding (this argument is developed further in Bush 2018 forthcoming, see also Collini, 2016; 2018).

The academic pressure restricting radical Africanist perspectives can impact the ways in which economic success and failure is characterised in Africa. My positionality has been honed over more than 35 years of engagement with African political economy and the obstacles placed in the way of critical scholarship. My relative independence from neo liberal sponsorship would not have been possible without engaged activity with the journal Review of African Political Economy. ROAPE has recently reinvigorated its outreach with Africa with a series of interventions that have been driven in particular by the promotion of radical Africanist analysis of contemporary dynamics of imperialism in Africa and working class and peasant resistance to it (Bush et al.2018). My conversation with the young participant at Ghent reminded me of the many strictures of the late Lionel Cliffe, who among many things was a founder editor of ROAPE:

'For individuals, old and young, who earn their living in academia: consciously or not we are making choices about our work agenda and our approach. Let's seek to make it our choice and not one forced upon us by institutional pressures and intellectual fashions. Let's examine our 'vocation' and be prepared to rebel' $(2012,222)$. The continuous theme that underpins this article is the task to understand and counter the impact of capitalism in Africa. There remains the overwhelming external domination of the continent and the context remains a history of underdevelopment and local classes 
of exploitation. My argument is that the current condition of African economies does not come from not being fully signed up to globalisation, thus opening itself further to pressures from the global financial and industrial corporates. It is in fact, contact with the global north that has consistently undermined, underdeveloped and impoverished the continent, albeit in an uneven way.

The hyped optimism of African development has once more waned. The outbreak of peace continues to be challenged by realities on the ground in DRC but also Libya, Egypt's Sinai, Mali, Western Niger and South Sudan. Although the over-optimistic rhetoric of 'Africa rising: the hopeful continent' (The Economist 3 Dec 20II) contrasts with the previously over-pessismistic 'hopeless continent' (The Economist, I3 May 2000) it is unclear how the voice of international business would describe Africa in 2018. Recent western commentary about Africa and the West's relationship with it was reinvigorated by the UK Prime Minister Tony Blair's Commission for Africa. Publication of the report in March 2005 coincided with Blair's chairmanship of the G8. The influential report was described as 'a coherent package for Africa' (CFA 2005:13 emphasis in original). The report helped set the scene for debates about Africa and the west and many academics with the IFIs supported a neo liberal characterisation of the continent's ills (Collier 2007; World Bank 2000; Moyo 20I0; Sachs $201 \mathrm{I}$ and for critique Harrison 2005; Lawrence 2010). Western politicians and IFIs focused on a new start for the continent as development became measured by a burgeoning middle class as an 'African Awakening' was heralded, although it is not always clear from what the continent was waking. UN's Economic Commission for Africa (ECA) has talked repeatedly about 'Unleashing Africa's Potential as a pole of Global Growth' (2012: 59) but in early 2017 the UN noted 'Commodity prices crash hits Africa' (Ighobor 2017,30). This headline reminded commentators that once again historically high levels of growth were not sustainable and did not represent economic diversification where value added was retained in Africa

We seem a long way from the view that the continent can be a source for global growth (Severino \& Ray 2012). Ex World Banker Jean-Michel Severino and erstwhile French Foreign Affairs Ministry economist Olivier Ray asserted the need not to look back in the 'rear view mirror' but forward with 'telescopes' to understand African development. They argued the importance of understanding Africa's complexity and not to see the continent as a 'newcomer at the feast of common prosperity'...'its headlong feverish rush to development can make its swarming youth one of the engines of world growth' (2012:265). The mention of Africa's youth is important. Two out of three Africans are under the age of 25. Reference to their 'swarming' is inappropriate, but it is a demographic that can influence and may shape policy if it can organise itself and mobilise without repression, to express discontent with hunger, unemployment and lack of opportunity.

The debate about African development and not looking back at the continent's history to help explain contemporary opportunity is crass. It implies that a sense of history roots analysis in the past only. Paul Collier for example, enthusiastically endorses Severino and Ray's Africa's Moment, lamenting, 'we need to get to know Africa again' (2012:2). And in doing so, instead of constantly recalling the horrors caused by colonial interventions of 
the slave trade, European genocide and imperialism we should focus on governance and the frailties of African leaders. This is an appealing message to Europeans who would rather forget their African atrocities than locate contemporary underdevelopment within an important historical context.

The consequences of the historically uneven incorporation of Africa into the world economy are important to grasp in all their devastating gravity. A detailed historical narrative is not necessary to indicate how contemporary dynamics of transformation and the hype that Africa can grasp the 2ist century obscures debate about exploitation and inequality that is a product of western entanglement as well as local class actors seeking to promote restrictive notions of 'development'. Views of development manufactured in the global north tend to dominate African policy discourse but a crude fossil fuel path to development in Africa would commit all of us to collective suicide (Klein 2015; Moore, 20I5). We need to look back and forward to understand African development challenges and the necessity to promote a radical structural transformation. Our vision needs to be shaped by understanding mechanisms of surplus extraction and the externalisation of the continent to see why and how debates about Africa's 'moment' have been recurrent and persistent and how they are also flawed.

There is a caveat to what follows, and this is the extent to which we can generalise about a continent of 54 countries. There are broad issues that help shape a general picture. Africa is the second largest continent and the second most populous. It covers 20 per cent of the Earth's landmass with $\mathrm{I} .2$ billion people, that is, almost $\mathrm{I} 7 \%$ of the world's population. I stress common features such as the continent's structural location within the world economy, export commodity dependence and similarities regarding de-industrialisation, unemployment and agricultural stagnation.

We can now review some of the optimism regarding African development and set it against long standing structural obstacles. In doing this I reflect on what development has come to represent and speculate where there may be political spaces for alternative and active resistance to mainstream policy and discourse about the continent which sees more capitalism as means of development, and poverty reduction. The optimism about potential for African growth and development quickly fades when confronted by the systemic features of post WW2 capitalism and the patterns of globalisation that followed the internationalisation of capital in the I950s and I96os.

\section{The optimism}

The heady optimistic days at the start of the 2ist century led the Economic Commission for Africa to strongly suggest 'that Africa is likely to make the twenty-first century its own' (ECA, 20I2:I). This matched World Bank rhetoric in 2000 that Africa could 'claim' the century (World Bank, 2000) as growth opportunities for investors were noted even by the more reserved Kofi Annan, Chair of the Africa Progress Panel (www.africaprogresspanel.org) who declared that while there is a long way to go 'Africa is on its way to becoming a preferred investment destination, a potential pole of global growth, and a place of immense innovation and creativity' (Annan, 2012a:3). 
Key measures for the continent's success were the gross domestic product (GDP) figures. Between 2002 and 2008 GDP on the continent grew by an average of 5.6 per cent. This meant Africa was the second fastest growing continent, at least for some of the time, behind Asia. And seven of the fastest growing economies in $201 \mathrm{I}$ were African (ECA 20I2:II-I4). The ECA asserted that many of these fast growing economies were not dependent upon oil and gas and 70 per cent of the people living in these economies were in countries that averaged economic growth rates over $4 \%$ for the last ten years. 'Development' was equated with economic growth with little analysis or reflection on either the veracity of the data or how GDP growth can translate into people's improved wellbeing and social justice.

The global capitalist crisis in 2008 impacted continental growth rates that slowed by 20II. The IMF reported in 2016 that growth had fallen to $3.5 \%$ for Sub Saharan Africa the lowest level for 15 years. Further falls were expected and a 'policy reset' was recommended to African governments as expectations from high oil rents needed lowering to avoid a fiscal crisis and deepening deficits. African economies could not withstand change in the external environment (IMF 2016). The roller coaster world of growth was helped by debt relief and increases in aid to Africa from 2004 but this source of financing was tempered after 2008 (OECD 2016). Between 1999-2008, the proportion of Africans living on less than $\$$ I. 25 a day fell from 58 per cent to 48 per cent - in effect, nine million people taken out of poverty according to the World Bank 2005-2008 (APR, 20I2:I6). And while many of the MDGs were not met, social indicators improved: fewer children were dying before their 5 th birthday and more were in school (APR 20I2: I7)

The explanations for these improvements and the optimism for Africa's claims on the 2Ist century had lain with western generosity to erase debts, many of which were odious and toxic. The rescheduling of payments ensured that finance continued to lubricate the world system without threat of defaults (Ndikumana \& Boyce, 200I). Central too was the generosity of donors with increased aid, although Global Alliances for Vaccines and Immunisations and increased access to anti-retrovirals, for example was driven less by western largesse and more by resistance movements of those with HIV/AIDs and African governments prepared to challenge the global dominance of pharmaceutical companies (Epstein, 2007). Access to anti-retrovirals grew from less than I4 per cent in 2005 to 43 per cent in 2008 (CAR, 2010:3).

\section{Interpreting optimism}

Closer inspection of the growth and development indicators suggests the need for a more cautious approach to understand the contemporary and persistent African crisis of capital accumulation and structural transformation.

Continental growth that had been trumpeted to have reached $4.7 \%$ in 20 Io was well below the proposed necessary sustained growth of $7 \%$ seen by the Africa Commission 2005 and World Bank as necessary for poverty to be significantly (and permanently) reduced (Africa Commission 2005: chapter 7). In fact by 2017 projected growth was just $2.4 \%$ up slightly from a dismal I. $3 \%$ in 20r6. In typically anodyne language the World Bank noted, 
'The outlook for the region remains challenging with economic growth remaining well below the pre-crisis average' (World Bank 2017 n.p.). The World Bank also noted slow growth in per capita income, which fell in 20I6/I7 and was inadequate to reduce poverty. African economies remain the least diversified in the world and the 2oro update from the Commission for Africa noted that 80 per cent of all African exports come from oil, minerals and agricultural goods (CFA, 20I0:I0). Only I2 per cent of growth comes from the agricultural sector, which accounted for 60 per cent of the workforce and is a clear indication of poor labour productivity. Conceding the difficulty of generalising growth and of the need for diversification the ECA tempered its upbeat assessment of continental political economy by noting:

'The last decade's impressive growth must be examined in a proper context if Africa is to become a global growth pole, for the fact remains that the sources of Africa's growth have changed very little over the years: agriculture and natural resources remain the main drivers, and Africa has diversified its economies in little meaningful way' (ECA, 20I2:I).

The structural imbalance in African economies that is seldom examined is that they are mostly characterised by a continuing overdependence upon rent rather than productive (manufacturing) growth. Capital intensive growth in labour surplus economies is a recurrent feature of underdevelopment. The failure to diversify economic growth away from hydro carbons increases vulnerability to the vagaries of the international market; failure of retained earnings; value added that accrues outside of the continent and the failure to break down enclave development. Thus inward investment made in parts of Africa, mostly in minerals and hydrocarbons, is used as evidence of the continent's grasp of the 2Ist century. Investment does not 'trickle down', but instead leaps over territorial boundaries. This makes it very difficult for state policy to intervene and harness any gains from the investment as it goes to limited spatial areas of extractives, minerals or agricultural wealth for export (Ferguson, 2007). Africa, moreover, still has only 3.4 per cent of the world's share of foreign direct investment US $\$ 59$ billion in 2016 a I.4\% fall compared with 2008 (UN 20I7: 45). In 20I6 FDI flows to Africa fell by $3 \%$ compared with the 2015 figure, from \$USD6r billion to \$USD59 billion in 2016 (UN 20I7: 46). The continuing significant issue is that just 5 countries, Angola, Egypt, Nigeria, Ghana and Ethiopia account for $57 \%$ of Africa's DFI flows (UN, 2010; 2016).

We should also note that at the macro-economic level GDP of SSA was just \$I. 5 trillion in 2016 with South Africa and Nigeria accounting for more than half of the continent's GDP (UN 2017: 44). In comparison, in 20I6 France's GDP was \$2.4 trillion, Germany's \$3.4 trillion and Belgium $\$ 466$ billion (www.Countryeconomy.com). In fact the output of the City of London is more than $25 \%$ of the size of the entire Nigerian economy whose GDP was $\$ 405$ billion in 2016.

Africa has received just 35 per cent of the promised increase in ODA made at the 3 Ist G8 Summit at Gleneagles 6-8 July 2005. But in 2018 there is a new unfolding African debt crisis. Debt relief mechanisms, The Highly Indebted Poor Countries Initiative 1996 and the Multilateral Debt Relief Initiative 2005 were hailed for reducing the debt burden for 
the poorest countries. The continent's external debt of about \$US443 billion in 2013 is described as manageable (UNCTAD 20I6). However, something very disturbing and not surprising has happened: a rapid increase in external and local debt. UNCTAD has noted with alarm:

'While Africa's current external debt ratios currently appear manageable, their rapid growth in several countries is a concern and requires action if a recurrence of the Africa debt crisis of the later I980s and the I9gos is to be avoided' (UNCTAD 20I6: 2). Africa's external debt stock grew rapidly by I0.2\% per annum $201 \mathrm{I}-20 \mathrm{I}_{3}$ from $7.8 \% 2006$ 2009. The increase was indiscriminate. Eight heavily indebted and $\mathrm{I} 3$ non-heavily indebted countries felt it acutely. Increased debt reflects enlarged (temporary) sources of funding from the BRIC economies (Brazil, Russia, India and China) but like the debt crisis of the I 980 s the risks linked to this relate to borrowing against the promise of sustained high commodity prices. These are not guaranteed and borrowing costs have spiralled. In addition African governments have borrowed increasingly from private lenders (UN 20r6: 3). This has crucially been at non-concessional rates, with loans that are more difficult to renegotiate and governments have entered Eurobond markets to try and secure funding for investment. The crisis is exacerbated by increases in private Africa debt (Elliott 20I8). If this requires a public bailout it will add to an already intense fiscal crisis of the stressed African state (UNCTAD 20I6).

The contradiction here, among others, is that the UN declared 2030 Agenda for Sustainable Development Goals noted that African development needed \$6oo billion - \$I. 2 trillion financing per annum. This is at a time of not simply the familiar donor fatigue and commitments not matched by delivery. These funding needs are relegated behind western focus on climate change, disaster prevention and management, securitisation of development and the continued war on terror. They have also fallen behind the EU's panicked rush to prevent an inflow of economic migrants and asylum seekers from Africa and the Near East (Global Health Advocates 2018) African governments have not always prioritised development financing needs. The self declared transition to middle income status for some, such as Ghana for instance has not been matched by changes in real income and wellbeing improvements for Ghanaians. It has, however, led to falls in multilateral funding, fiscal deficits, depreciation of the cedi (local currency) and inflation (ECA 2018 forthcoming). And we now know much more clearly the ways in which African government national accounting has managed to construct a fictional middle income status as well as why figures for African growth and GDP accounting are so flawed (Jerven 2015).

The Africa Progress Report may be the most reflective of commentaries from the array of international agencies and IFIs that offer accounts of Africa's potential for development. Persistent inequality has been critiqued as 'ethically indefensible...economically inefficient and politically destabilising' (Africa Progress Report 20I2,2). The Progress Report has noted that almost 400 million Africans struggle on less than \$I.25 a day and that despite economic growth the continent accounts for a rising share of world poverty - up from 2I per cent in 1999 to 29 per cent in 2008 (2012,I6). Africa is the continent 
with the highest proportion of children in extreme poverty, $49 \%$, and the number of poor Africans rose from 288 million in 1990 to 389 million in 2012 (Beegle et al.2016). The poorest 20 per cent in Sub Saharan Africa moreover, typically receive 6 per cent or less of national income and the poorest 40 per cent in most cases receive less than 15 per cent (Africa Progress Report 2012). An issue that is seldom explicitly examined in the IFI documents on African development is the relation between growth and inequality. International agencies do not explore the idea of poverty and inequality in relational terms other than to assert that growth will trickle down. The empirical evidence, some of which I have assembled in this article, is that in contrast there has been increased dispossession and abjection of the poor and the cascading up of wealth at the expense of the poor (Bond 2006; Bond and George 2003; Bracking 2016).

Inequality was a key driver of the revolutionary uprising in Egypt in January 20Ir. Yet Egypt had experienced sustained per capita economic growth of more than 3 per cent over Io years (Achcar 2013) - growth figures that most developing countries desire. However, more than 50 per cent of Egyptians lived on less than $\$ 2$ a day - up to 8o per cent in the countryside: how do we explain that Egypt developed in GDP terms but in terms of improved livelihoods Egyptians did not? (Bush 2004; Bush 20I2).

The IFIs have tried to disguise the persistent structural levels of poverty and inequality in Africa by asserting that there has been the growth of an African middle class. This has been defined as those who live on an income of more than \$ro a day. The hope that a middle class will boost African development is fraught with definitional difficulties and an ideological over-reliance that this newly emerging class will have resources and incentives to invest in the provision of public goods rather consumer durable commodities bought with valuable and scarce foreign exchange (cf Kharas 20II and Melber 20I7). According to the Brookings Institute, membership of the global middle class is defined in the range of earning \$ro-\$10o a day. Using these figures Africa accounts for 2 per cent of the world middle class population and I per cent of its purchasing power (APR 20I2:I7). Empirically there has simply not been investment from a middle class, old or new to boost development that reduces inequality. While there is evidence for growth it has seldom been translated into development, a lessening of poverty and inequality and investment in the production of wealth that is sustainable and can be used, among other things to produce a sustainable industrial strategy (Lawrence 2018)

The optimistic interpretation of Africa's development trajectory simply does not add up. The MDGs were not met, although a positive spin was placed on them. Granted there are more women in African parliaments, improved maternal and infant mortality and because of advocacy pressure on the continent there has been improved treatment for people with HIV. But there continues to be immense inequality in the provision and access to social services, health and education, employment especially for women and young people and for economies unable to deal effectively with shocks such as Ebola (UNECA 20I5). 


\section{Structural transformation and African underdevelopment}

At the heart of the debates in the donor communities and the IFIs is a continuous strand of modernisation, to more fully integrate parts of the continent into the world economy - namely the minerals and hydrocarbon producing economies and to ensure that Africans in the continent remain there, and do not try to come to Europe (European Union 20I8a; 20I8b and the critique inter alia Global Health Advocates 2018).The strategy for the mineral producers is simple: at best promote an agenda of transparency and openness for good governance and engagement with civil society actors like Publish What You Pay, Extractives Industries Transparency Initiative and so on. The strategy for 'development' elsewhere on the continent, for smaller land locked economies, is the provision of development assistance that provides for bare life (Duffield 2007) and or securitisation as in the Sahel with AFRICOM and anxiety and intervention against pastoralist mobilisation in Mali, Kenya and elsewhere (Keenan 2009; Cross, 2013).

Donors have been unable to move from agendas of charity and good conscience and where they may have done so it is to promote a securitisation agenda on the continent. As Rita Abrahamsen has noted in detailing the context in which this agenda emerged, 'More than any other part of the globe, Africa has in the post-Cold War period been associated with conflict, insecurity and human rights atrocities' There was first Robert Kaplan's (I994) vision of Africa as a nightmare of ethnic violence and state collapse and then, after September II 200 I (9/II) destruction of the twin towers in New York, Africa was viewed as a continent with 'ungoverned spaces' that enabled terrorists to hide while they plotted the demise of Western civilisation (Abrahamsen 20I3: I; see also World Bank 20II and Duffield 200I). This in part is a strategy to prevent African migrants reaching European shores as with fortress Europe elaborated in FRONTEX, the EU's 'border management' strategy, while simultaneously talking about the importance of development in Africa (Cross, 2013). The rhetoric recommended a strategy for African development that is one of western modernity and industrial growth, yet this is absent in practice and under existing global dynamics and local management it is impossible. The continent fails the targets for development where they are consistently western driven and constructed. An over-reliance on Chinese or Indian investment to provide an alternative and sustainable strategy for growth, in terms of being more labour intensive, using local resources for local value added, regional connectivity and generating local effective demand is nowhere yet evident. An exception may be the case of Ethiopia but even there the manufacturing share of GDP remains stubbornly low (UNDP n.d.; World Bank 2015).

The contemporary language of the IFIs is to use the term 'structural transformation'. For the ECA it means 'unleashing Africa's potential as a pole of global growth' with a strategy of political leadership, national (sic) development and mobilisation of a middle class for private sector investment (ECA, 2012:2). What has emerged is a narrative that celebrates growth since 2000 and was based on improved governance and economic management, reduced levels of corruption and growth in new service sectors. But as we have seen when scrutinising the economic data, at a time of great optimism there remain structural and persistent crises. And where there is an assumption that the market and a middle class can 
drive growth it is not evidentwhere and how this will happen. The World Bank (2017) affirms an interpretation of structural transformation that has actually led to deindustrialisation on the continent, service sector growth that has not reduced job precariousness and low productivity, and an agricultural sector that remains underdeveloped despite the fact that it is still the largest employer (Bush et al. 2018). In contrast we might investigate structural transformation to mean an industrially-centred transformation, broadly defined this is where there is, among other things, a greater use of local resources and retained value added from production in an attempt to reverse the continent's outward facing structure and dependence on the deleterious impact of foreign capital.

Africa's underdevelopment was set in motion by informal colonial transformation from the I4th century (Amin 1972). It has been exacerbated by the immeasurable damage resulting from neo-liberal reforms after the early i970s. As Giovanni Arrighi (2002) noted in exploring Africa's tragedy, the continent grew, often more quickly than elsewhere and in a sustained way after WW2. Driven by high expectations and state managed economies (although not always without managerial difficulties); the ig6os witnessed an emphasis on infrastructural growth and investment in productive industries. Import substitution industrialisation was seen as acceptable and official development assistance or AID to offset inadequate local savings could be used to boost economic growth and cope with foreign exchange shortages.

In the international economic crisis of the I970s, however, Africa was simply less well equipped to deal with global transformations. As Arrighi again noted, 'some countries or regions have the power to make the world market work to their advantage, while others do not, and have to bear the cost' (Arrighi: 2002: I6). This may be seen to lie in good or bad luck that has 'deep roots in a particular historical heritage that positions a country or a region favourably or unfavourably in relation to structural and conjunctural processes within the world system'. Africa's tragedy, if that is an appropriate word, lies in its 'precolonial and colonial heritage which has gravely handicapped the region in the intensely competitive global environment engendered by the US response to the crisis of the I970s (Arrighi, 2002:16).

The damage done to Africa and by African leaders who colluded with structural adjustment in the I980s continues to be felt. The lost development decade was marked by dramatic increases in unemployment and the destruction of health and welfare provision. African infrastructure and wellbeing was destroyed, and states that had the temerity to seek independent trajectories for development were disciplined. Ghana's President Kwame Nkrumah's dictum of seeking first the political kingdom now rang hollow. $\mathrm{He}$ had been ousted from power by a US backed coup in I966 and after Patrice Lumumba's assassination in $196 \mathrm{r}$, Zaire became a haven for anti-communism and terrorist interventions in southern Africa (Nkrumah 1976; Reyntjens 2009). More and more it seemed the answers to the 'central historical question' (Rosenberg, 2006 in Brown \& Hanlin 2013: 5) as Eric Hobsbawm called the development challenge, were peddled by the west. Eduardo Galeano noted development became the 'promise of politicians, and justification of technocrats, the illusion of the outcast' (I997:214). 
Something fundamental happened in the 1980 s and it continued. It was no longer possible to see 'development conceived of as a project for change undertaken collectively by the population of a single, medium-sized country, acting through the state' (Leys,I996:4I). The I980s see the erosion of controls of capital, expansion of financial markets where not only African states had difficulty setting their own exchange rates and with this there was the loss of control over fiscal policy and state spending (Leys,1996:42). Per capita growth rates in SSA fell as deregulation emerged. The period of national liberation, from WW2 to the defeat of US imperialism in Vietnam in 1975, was characterised by the Chinese Communist party as 'countries want Independence, Nations want Liberation and People want Revolution' (Shivji 2003: I09). In southern and Lusophone Africa especially, but elsewhere too where there had not been armed struggle, there had seen a sense of direction and purpose to establish a new liberatory post colonial politics. There was widespread optimism and hope in Africa for development with social justice and there were strong illustrations of critical support and engagement with progressive movements (Chutel 2016; ROAPE 1976). In Egypt, Gamal Abdel Nasser had expanded his vision to control the commanding heights of the economy to drive industrial growth, promote land reform and alleviate rural poverty. But beginning in the 80 s there was an onslaught on the possibility of a locally constructed and meaningful development strategy. To cite Colin Leys again, 'It is hardly too much to say that by the end of the I 980 os the only development policy that was officially approved was not having one-leaving it to the market to allocate resources, not the state (Leys,I996:42; see also Bracking \& Harrison 2003; Bracking 2003).

Catching up with the west, if it had ever been possible was certainly not feasible. The context of changed international neo-liberal circumstances, of structural adjustment, demands by IFIs and donors to reduce state intervention as a strategy to improve market efficiency, undermined what capacity existed locally to deal with turbulent international demands (Meager 2003; Biel 2003). Failure to comply generated widespread criticism of Africa. The critique of African states by the IFIs and donors ultimately offered an account of Africa as the child, who needed constant help or, alternatively as a renegade 'failed' state that needed protection from itself (Ayers 2006). This protection might be offered by new forms of 'trusteeship' or intervention (Collier, 2008) necessary to get African states back on track. The trusteeship of surplus peoples has perhaps been a continuous feature of post WW2 (Cowen and Shenton (I996). President Truman's January I949 speech indicated the need to help the least fortunate members of the human race and that somewhat self serving aid mentality has continued as the fear of global inequality especially post 9/II is seen to have aggravated southern dissent with the western way of life. Development in Africa, as we indicate further below, has become securitised as the focus of the IFIs and donors may now be to maintain minimal living standards in a context of humanitarian and development rhetoric (Duffield, 2007; Arendt, I958; Bauman, 2004; Evans, 2013). Binyavanga Wainaina $(2005 ; 2012)$ captured the persistent view of Africa as child and mysterious 'other'. Paternalism and religiosity he argued is cover for Africa's continued subjugation and the power of the west to shape development agendas but it does not do 
so without resistance. Much of the mainstream literature and accounts that have promoted the Africa rising trope exclude analytical stock taking of the consequences of Africa's historical past. This may account for why the continent's development difficulties have been explained in terms of poor state capacity - something that was undermined anyway by western SAP policy in the I980s (Campbell 20II). It also helps explain why the strategies offered to the continent's leaders inevitably involves further incorporation into existing globalisation rather than any possible alternative routes. And it explains the pathologising of politics in Africa by western commentators and IFIs that persist with narratives about weak states, tribalism and the politics of ethnicity (inter alia, Collier; Bayart I989; Chabal and Daloz I999; for the anti-dote, Allen I995 and Szeftel I998; Gruffydd Jones 2008; Bracking 20I6).

\section{Capitalist exploitation and resistance}

We can now return to the structural impediments that prevent African growth becoming more equal and sustainable. We can also look at the ways in which struggles in the continent have challenged impoverishment and uneven growth. By doing this we can indicate how the political spaces that may be opening up might provide a context for development and social transformation with justice and greater equity at its core.

There is little connectivity between the IFI desires to demonstrate how well the continent is progressing, by focussing on improved macro economic GDP indicators, and the complaints raised by the Economic Commission for Africa about illicit financial flows from Africa. As chair of a UN committee that investigated illicit flows from Africa, erstwhile SA President Thabo Mbeki noted, the bulk of multinational corporate company earnings of \$I.5 trillion in Africa each year are transferred out of the continent. These transfers avoid taxation, drain African economies of crucial liquidity and hard currency and accelerate income inequalities (ECA 20I2a:np, Bracking 20I6).

Multinational Corprations (MNCs) control about 6o per cent of world trade, about \$40 trillion dollars, and Mbeki's committee noted that perhaps as much as $\$ 22$ billion is transferred out of Africa illicitly each year - a significant proportion of the continent's debt and development assistance. In this context corporate social responsibility seems a long way from delivering the potential for development as the major banks are implicated in these transfers as are the big mining and oil and gas companies.

There thus seems to be collusion between some local African elites, special foreign interests and a 'wilful blindness of Western financial institutions and governments' (Ndikumana \& Boyce, 2012:2). In 2010 a number of African leaders were implicated in illicit wealth creation, including the presidents of Republic of Congo, Gabon and Equatorial Guinea. All of these leaders were accused of embezzling public money. Each was in charge of running oil economies where the per capita incomes were some of the highest on the continent but where poverty and inequality was some of the greatest (Global Witness 2009).

Capital flight is a major block to sustainable development in Africa. Capital flight takes the form of direct embezzlement by politicians or fraud and under-invoicing of oil ex- 
ports and over-invoicing of imports. The IMF estimates that \$4 billion of Angola's oil wealth in 2002 was unaccounted for - \$7 I billion went 'missing' in the period I985-2008 and there are similarly staggering figures for Ivory Coast, Cameroon and Sudan (Ndikumana and Boyce, 2012:4). Although the volume of capital flight may be greater from Asia the outflows from SSA 2005 -20I4 average between $7.5 \%$ and II.6\% of the region's total trade. One estimate is that for every dollar of external borrowing 60 cents exits the continent as capital flight (Boyce 20I5, n.p.).

It is not only capital flight that has enabled African elites closely tied to some states and mineral economies to benefit from globalisation. The development experience of the I980 and the new modes of accumulation that it spawned helped promote a new growing class of very rich African entrepreneurs. These have emerged from strong links with global capitalism in real estate promoting high end consumerism, and new consumer markets that are very visible in Accra and Luanda, Nairobi and Johannesburg. Africa's growth figures are shaped by commodity price rises and bourgeois consumption patterns, not by productive investment in local revenue generation.

The new African class of entrepreneurs in whom so much is invested by the IFIs has provided cover for the failures of de-industrialisation and the redefinition of structural transformation used by the IMF. Africa's share of manufacturing in economic output fell from more than $\mathrm{I}_{2} \%$ to about II\% between I980-20I3. Several different UN agencies have repeatedly sounded the alarm about the continent's crisis of manufacturing. In 2012 UNCTAD noted 'The declining share of manufacturing in Africa's output is of concern because historically manufacturing has been the main engine of high, rapid and sustained economic growth' (UNCTAD, 20I2: 2-3). And twice more recently the ECA (2016) and UNIDO (20I6) have lamented the failure of structural transformation that embraces the delivery of policy and practice that boost sustainable manufacturing. UNIDO notes how without manufacturing and industrialisation more generally Africa will not meet the SDGs by 2030; that inclusive and sustainable industrial development boosts employment, sustainable livelihoods, innovation and skills and in so doing also provides revenue for social and infrastructural development (UNIDO 20I6, I). We have noted, however, how the absence of growth in manufacturing undermines job creation, improved service provision and meeting youth expectations for work and improved lifestyles. The IFI response has repeatedly been that Africa continues as a raw material exporter (for western and Chinese needs) while offering some mediation of 'dependency' with profitable transnational corporate telecom development and financialisation of activities like banking and real estate. But this is precisely the 'development' resting on continued speculation of African markets that has helped create Africa's recent post 2008 phase of impoverishment and deindustrialisation. Commodity booms have not led to industrialisation yet we know that:

'Rarely has a country evolved from poor to rich without sustained structural transformation from an agrarian or resource-based economy towards an industrial or service-based economy' (UNIDO 20r6,I).

It is this transformation that enables wealth creation on the back of improved economic integration and productivity. In contrast IFI driven structural transformation has un- 
dermined state intervention, beginning in the I980s, and has destroyed the provision of public goods. The IFIs continue to utter the ideological mantra and practice that private investment promotes growth. However, as I have indicated, with 'no industrial policies or financial institutions to underwrite industrialisation, African economies have not been able to enhance the interface between raw material production and manufacturing' (Mkandawire, 20I4, I76). This critique of the IFIs and especially the continued stagnation of manufacturing value added as a proportion of GDP is overwhelmingly obvious and the figures for Africa are the worst for any part of the world (Taylor, 20r6).

There are several illustrations I might use to offer a sustained critique of the status quo and everyday resistance to Africa's persistent underdevelopment. Space will only allow me to mention one set of dynamics where the issue of the plunder of Africa's resources is met by a combined challenge from communities affected by mining and by a pan African initiative to both constrain mining companies and to promote local industrial development.

Mining companies might be seen as outriders for imperialism (Bush 2010). It is still too early to make a definitive judgement about the impact of Chinese mining companies in Africa. Extractives remain a small proportion of global FDI yet it has a disproportionate economic and political influence on African development and economies. This is because of the importance of minerals in manufacturing and industry more generally as well as to the military (Willett 2009; Reno I996; Watts 2007; Obi 2010). Mining companies are at the forefront of accumulation by dispossession in Africa. In doing so they promote a crude mantra of modernisation theory and promote the asymmetrical relationships that permeate mine areas, establish hierarchical relationships of power and exercise violent, intimidating control from mining enclaves. Enclaves are the result of FDI that does not permeate beyond the spatial location of extractive locations. They are the source of capital intensive production in the context of labour surplus. The mining enclave is organised for large scale production and there is frequent intimidation of local inhabitants by mine operations and by mine security that stops local residents from entering mine areas.

Two general types of violence prevail in mining enclaves in West Africa: a political violence where global corporates can bypass government decision making and consultation and a more familiar coercive violence where mines are cordoned off, policed and locals who enter get attacked. Where enclaves are fenced off, local communities are denied access to forestry resources and hunting, and all too frequently subject to the toxic waste that pollutes local water sources (Ochieng et al. 20I0; Owusu-Koranteng and Owusu Koranteng 2017). In such circumstances a more complex set of relationships may emerge that goes beyond my twofold characterisation of violence. A more nuanced problematisation of the 'economies of violence' is evident in the Democratic Republic of Congo (DRC) for example. In eastern DRC rebel groups have engaged in a range of activities that go beyond, but can sometimes still be linked to, minerals. Conflict has been associated with military groups controlling land rather than minerals (Vlassenroot and Huggins 2005). Military groups gain access to taxing local communities, controlling border posts in areas where the formal state is ineffective or colluding with militias. Local militias have 
also gained from looting, trading in hemp and charcoal and stealing livestock collecting roadblock taxes and taxing local agricultural producers (Laudati 20I3:33, 35).

The enclave is in many ways a metaphor for broader, persistent and systemic exploitation in Africa. It was most violently witnessed in South Africa in August 2012 at Marikana's platinum mine run by LONMIN where 47 miners were gunned down by police in response to a strike over pay and conditions (Marinovich et al, 29 January 2013). The main characteristics of an enclave relate to the violence and human rights abuses but also the ways in which expatriate labour accompanies the mining investment - as if to guard over it. The essential observation is that the enclave is a mechanism to promote the externalisation of the African economy (Ferguson 2007). It provides a way to extract resources and profits and in so doing provides an example where local government decision making is frustrated. Local planning mechanisms, guarantees of employment, access to tax revenue, and support initiatives for local African entrepreneurs to benefit from mining in the enclave are susceptible global market fluctuations in commodity prices. This does not mean that there may not be some local beneficiaries of the enclave. It does mean however, that the promises made by the mining companies and their representatives that communities can and will benefit from mining are false (Mine various issues) The enclave does not add to the expansion of the local and domestic market savings ratio and growth of a local bourgeoisie: it provides a block to each of these (Mhone, 200I).

In West and Central Africa there has been collusion between African states and mines operating in the enclaves. That has suggested compliance with the rhetoric that FDI will drive growth. 'Kick backs' can also accrue with rentier politics (Global Witness, 20I2). Yet there has also been opposition and resistance to mines, mining and extractive social relations. While there may be some variance depending on the historical patterns of mining acitivity, the scale, role and extent of foreign national and local government engagement, resistance has emerged from two main areas. This observation is based on mining in west and central Africa but it is also evident in southern Africa. There may be different experiences elsewhere on the continent where there has been heightened violence or militarisation of links between minng companies, communities and the state. Indeed the state can be problematised as the arena in which several different economic actors compete for power to deliver policy and declared mining policy outcomes. Resistance has first been centred in communities themselves and may be characterised as reflecting the 'quiet encroachment of the ordinary' (Bayat, 2009). Writing about urban unrest in the Middle East, long before the 20II Arab uprisings Bayat explored:

'non collective direct actions of individuals and families to acquire basic necessities (land, shelter, urban collective consumption, informal jobs, business opportunities) in a quiet, unassuming fashion' (Bayat, 2000:iv).

These actions are not just a defensive coping strategy regarding land loss and challenges to livelihoods. Community and other localised struggles can also advance the livelihoods of ordinary people, and these sometimes fleeting struggles may occur without obvious leadership and formal organisation. In Bolivia for example, struggles against water charging and the nationalisation of gas emerged from social movements that drew on 
the 'strength from their embeddedness in daily life' (Spronk \& Jeffery, 2007). In many parts of Africa, struggles waged by artisanal small scale miners (ASM) over land access and control of equipment and inputs for mining might contribute to everyday resistance to owners of land and capital.

There may be more than Io million such miners in Africa, and I.I million in Ghana (an additional 4.4 million dependents) where they are known as galamsey. Most of the discussion about the galamsey centres on their legal status and the extent to which they degrade the environment (Hentschel et al., 2003). ASM may be seen to be a strategy not just of survival and livelihoods, and there are complicated relations between miners and funders, land owners and communities - exacerbated in recent years by a large influx of miners from China (Crawford and Botchwey 2018). These have been middlemen and financiers, companies as well as labourers who were often miners in China and who are now mining in Ghana and elsewhere in West Africa. ASM may also be seen as a strategy that confronts commodification of land resulting from mine concessions and enclave development (Bush 2009). ASM can be seen as a social (and political) response to the internationalisation of capital and its deleterious consequences that have abjected communities affected by mining.

Running alongside the ASM debate that has mostly focussed on its deleterious environmental impact and lawlessness (Bush 2009) is the African Union's Mining Vision initiative (African Union 2009; 20II). This mining policy and strategy document is an example of a locally generated African initiative and one that is intended to be operationalised by African governments. It was developed to promote a resource based development and structural transformation of the continent. It has been an important attempt to promote an independent transformation of mining discourse to implement a pan African policy that challenges decades of underdevelopment by mining companies (African Union 20I6). At the heart of the AU policy is the desire to maximise revenue from extractives for an industrial agenda. Mining is used as leverage for structural transformation. The Vision aims to promote the 'equitable and optimal exploitation of mineral resources to underpin broad-based sustainable growth and socio-economic development' (African Union, 2009:4). In doing so the AU has put back on the AU policy agenda the need to revisit the historical underperformance of government access to revenue from local resources. The AU has also declared the need to re-examine the debate about the relationship between regulation and control of mines that was very much part of the nationalist I970s agenda (Andreasson 2015).

Crucial for the AU is an understanding of Africa's past, of underdevelopment and reference to the much maligned I980 Lagos Plan of Action that among other things highlighted the exploitative nature of colonial transformation, western corporate dominance and the challenges to African state capacity (OAU I979). The AU vision may be an attempt to think outside of the 'mining box' - to counter the consequences of capital intensive extractives and to avoid the recurrent development failures of the extractives enclave. It was an attempt to resurrect, an agenda, albeit in a different global environment from the I970s, that will accrue greater benefits for host countries and mining communities. At- 
tempts have been made to reduce old impediments to developing a pan African policy. In 2013 an African Minerals Development Centre was established to coordinate actors like UNECA, the African Development Bank and UNDP (https://www.uneca.org/amdc). This Centre may help improve the speed with which pan African decisions can be made and there has certainly been a shift since the Mining Vision in 2009 to begin to focus on possible national as well as regional mining initiatives that can better reward and retain local value added for domestic development initiatives. For example, the new AMV African Minerals Governance Framework (ECA 2017) was designed to deepen commitment to implement the AMV, to accelerate an alignment of mining laws and policy and to improve sharing of good practice in the ways in which African states work alongside stakeholders like the mining companies (ECA 20I7,v-vi). The AU initiative has begun to shift the ground and issues for debate. It is a debate that has been partly shaped by the discourse of neo extractivism in Latin America (Burchart \& Dietz 20I4; Veltmeyer 20I6; Veltmeyer and Petras 20I4). It has sought to restore a central role for the state, for example, and improve governance, transparency and accountability of firms and state institutions (Greenspan 20I4) and action.

The AMV deals with contentious issues. There is likely to be many conflicts. These will be within and between African states regarding the development and implementation of policy. Those conflicts will be intense if there is a real attempt to try and increase control of national resources for local development limiting mining company activity. And this will be intense too if MNCs try and pick off different states to play them off against each other for competitive advantage, among other things. The structural dependence of Africa mineral economies continues and it will be difficult to develop alternatives where the primary source of revenue is mining. For the moment too there is no nation state champion (Graham 2015) that can drive the AMV agenda of sustainable more equitable development based on extractives. The AMV has nevertheless set an agenda to avoid the persistent race to the bottom and to do so with a goal of promoting structural transformation to gain benefits from value added locally with higher volume of locally sourced inputs, infrastructure and gains from beneficiation. Hence there has been the development of national mining visions that promote policy to scale up local development through greater retention and improved local content (ECA 2018 forthcoming; Cosbey and Ramdoo 2018).

\section{Conclusion}

I have among other things highlighted that the debate about Afro optimism and pessimism, Africa rising and falling is a popularised discussion that has tended to ignore the need to grasp the structural processes underpinning headline economic growth figures. The 'scramble for Africa' continues. I have indicated the importance of going beyond headline figures bandied around by the IFIs, and apologists for global capitalism to interrogate what is currently a dominant vision of structural transformation of African economies. IFI policy created a structurally transformed Africa that has impoverished agriculture, restricted industrial growth and promoted the extractive sectors for the benefits 
of MNCs and the domestic economic and political interests around international rather than national market growth.

The challenge, as this article has begun to map out, is to assemble analysis and action to construct and build a radical transformation of Africa. There have been examples of radical agendas in recent years, Burkina Faso, Egypt and Tunisia, to name just three, all of which have failed to deliver on early expectations. Future activism and engagement for radical transformation will explore class and social movements that struggle to defy injustice and help construct alternatives to the IFI, donor and government policy that has so ensnared and undermined the well being of the majority of Africans.

I have indicated hope in the AMV as a vehicle that might be used with pressure from below to promote sustainable and more equitable development in Africa. It is timely given the passing in August 2018 of Samir Amin. He made repeated calls in his life as a committed Marxist activist in Africa for socialist transformation that autocentred development was possible. By this he meant the possibility of delinking, not autarky, from the imperatives of globalisation. He argued for 'sovereign popular projects' where delinking from the world economy would help create local economic rationality with a 'national foundation and a popular content, independent of the criteria of economic rationality that emerges from the domination of the law of capitalist value that operates on a world scale "(Amin I987: 436; 2013; 2017). Promoting this would ultimately help stimulate sustainable and equitable development in Africa led by peasants and the working class.

\section{Aknowledgements}

Thanks to Peter Lawrence and Yao Graham for their time and commitment.

Thanks for comments from an anonymous reviewer.

\section{References}

Abrahamsen, Rita (2013) Introduction: Conflict \& Security in Africa in Rita Abrahamsen ed., Conflict \& Security in Africa. Woodbridge, Surrey. James Currey

Achcar, Gilbert (2013) The People Want. A Radical Exploration of the Arab Uprising Saqi Books, London

Africa Progress Panel (2012a). Jobs, Justice and Equity, Africa Progress Report 2012 (available from www. africapresspanel.org)

- (2012b). Jobs, Justice and Equity, Africa Progress Report 2012 (available from www.africapresspanel.org) Extracts from the Report

African Union African Mining Vision (2009) http://www.africaminingvision.org/amv_resources/AMV/ Africa\%2oMining\%20Vision\%2oenglish.pdf

- African Mining Vision (20II) http://www.africaminingvision.org/amv_resources/AMV/Action\%20 Plan\%20Final\%20Version\%20Jan\%202012.pdf (December) (Accessed 22 February 2013)

- (2016) African Women in Artisanal and small scale mining available at https://www.uneca.org/sites/ default/files/PublicationFiles/women_in_artisanal_and_small_scale_mining2015_en.pdf (accessed 2 August 2018)

Amin, Samir. (1972) 'Underdevelopment and Dependence in Black Africa - Origins and Contemporary forms' in Journal of Modern African Studies Io, 4, pp503-524

Amin, Samir. (2017a) 'The Sovereign Popular Project: The Alternative to Liberal Globalization', in Journal of Labor and Society 20, I, March, pp7-22 
Amin, Samir (20I7b) 'Revolutionary Change in Africa: an interview with Samir Amin' Interviewed by Leo Zeilig in Dakar, 5 February available at ROAPE.net (accessed I4 August 20I8)

Amin, Samir (I987) 'A note on the concept of delinking' in Review vol Io, 3, Winter, pp435-444

Andreasson, S. (2015) 'Varieties of Resource nationalism in Sub Saharan Africa's Energy and Minerals Markets', The Extractive Industries and Society, 2,2,pp3rorg

Arendt, Hannah [195I] (I994) The Origins of Totalitarianism. New York, Harcourt.

Arrighi, Giovanni (2002). 'The African Crisis' New Left Review II, May/June, pp5-36

Bayat, Asef, (2000) Social Movements, Activism and Social Development in the Middle East. UNRISD Progrmme Paper on Civil Society and Social Movements. PP CSSM 3, Geneva: UNRISD

- (2009) Life as Politics. How ordinary people change the Middle East. Stanford, University Press.

Biel, Robert. (2003) 'Imperialism \& International Governance: The case of US Policy towards Africa' Review of African Political Economy vol3o, 95, pp77-88

Beegle, K., L. Christiaensen, A. Dabelen and I. Gaddis, (20I6) Poverty in a Rising Africa. Washington. World Bank Group

Bond, Patrick, (2006). Looting Africa. London, Zed Books

Borras, Saturnino, M. (20I6) 'Land politics, agrarian movements and scholar-activism', Hague, International Institute of Social Studies

Boyce, James. (2015) 'Capital Flight from Africa: What is to be done', UN Head Quarters 23 October http://www.un.org/en/ga/second/7o/oct23umass.pdf (accessed I5 January 2018.

Bracking, Sarah. (20r6) The Financialisation of Power. How financiers rule Africa. London. Routledge

Bracking, Sarah and Graham Harrison (2003) 'Imperialism \& New Forms of Accumulation', Review of African Political Economy vol3o 95, March pp5-ro

Brown, William \& Rebecca Hanlin (2013). 'Introducing international development', in Theo Papaioannou \& Melissa Butcher eds., International Development in a Changing World, London. The Open University, Bloomsbury Academic

Bush, Ray, Yao Graham and Leo Zeilig (2018). 'Structural transformation in Africa today: interventions from the left' Review of African Political Economy 45, I56, June pp 267-274

Bush, Raymond C (2013). 'Making The 2Ist century its own: Janus faced African (under)development' , Afrika Focus vol 26, number I, 20I3, pp 5 ${ }^{\mathrm{I}-65}$.

Bush, Ray (2012). Marginality or abjection? The political economy of poverty production in Egypt, in Ray Bush and Habib Aye beds., Marginalilty and Exclusion in Egypt Zed Books, London

Bush, Ray (2010). 'Mining, dispossession and transformation in Africa' in Alastair Fraser and Miles Larmer eds Boom and Bust on the Zambian Copper Belt Palgrave, London

Bush, Ray (2009). 'Soon there will be no-one left to take the corpse to the morgue': Accumulation and Abjection in Ghana's mining communities', Resources Policy 34, pp 57-63

Bush, Ray (2007). Poverty and Neoliberalism. Persistence and Reproduction in the Global South Pluto Press, London

Campbell, Bonnie. (20II) 'Corporate Social Responsibility and development in Africa: redefining the roles and repsosibilities of public and private actors in the mining sector' Resources Policy July available at http://www.ieim.uqam.ca/IMG/pdf/BCampbell_-_20II_Corporate_social_ responsability_-_Resources_Policy.pdf (accessed I3 August 2018)

Chutel, Lynsey (20I6) 'Africa is not conflicted about Castro's legacy' Quartz Africa November 26, available at, https://qz.com/africa/846337/cuban-leader-fidel-castro-was-a-liberation-icon-inafrica-and-remained-committed-to-the-continent/ (accessed ro August 2018)

Cliffe, Lionel (2012). 'Neoliberal accumulation and class: a tribute to Gavin Williams' Review of African Political Economy 39,I32,June, 213-224

Collier, Paul (2008) The Bottom Billion, Oxford, Oxford University Press 
Commission for Africa (2005). Our Common Interest: Report of the Commission for Africa, March, London, CFA.

- (2010). Still Our Common Interest, March, London, CFA.

Commission of European Communities (2008) The Raw Materials Initiative 4 November http://eur-lex.europa.eu/LexUriServ/LexUriServ.do?uri=COM:2008:0699:FIN:EN:PDF

Cooper, Frederick (2002). Africa since 1940. The past of the present. Cambridge, Cambridge University Press.

Cowen, M.P. \& R.W.Shenton (1996) Doctrines of Development, London, Routledge. https://countryeconomy.com/gdp/france?year=2016 (accessed ro August 2018)

Crawford, G and G. Botchwey. (2018) 'Militarisation and Criminalisation of ASM: the state and the so called 'galamsey menace' in Ghana', Review of African Political Economy (forthcoming)

Cosbey, Aaron and Isabelle Ramdoo (2017) Guidance for Governments Local Content Policies. July Intergovernmental Forum on Mining, Minerals, Metals and Sustainable development available at https://www.iisd.org/sites/default/files/publications/igf-guidance-for-governments-localcontent.pdf (accessed I5 August 2018)

Cross, Hannah (2013) Migrants, Borders and Global Capitalism. West African Labour Mobility \& E U Borders. London, Routledge.

Davis, Mike (2007). Planet of Slums. London, Verso.

Duffield, Mark (2007). Development, Security and Unending War. Governing the World of Peoples. Cambridge, Polity.

Duffield, Mark (200I) Global Governance and the New Wars. London. Zed Books

Elliott, Larry (2018). 'Another developing world debt crisis is on the way unless everyone acts now', The Guardian I5 January,pp42-43

Ellis, Stephen (20II). Season of Rains Africa in the World. London, Hurst and Company.

Epstein, Helen (2007). The Invisible Cure. Africa the West and the Fight Against AIDS. Farrer, Strauss and Giroux

European Union (2018a) EU Trust Fund for Africa: additional $€ 90.5$ million to strengthen border management and protection of migrants in North Africa 6 July available at http://europa.eu/rapid/press-release_IPI8-4366_en.htm (accessed I August 2018)

European Union (20I8b) https://eeas.europa.eu/sites/eeas/files/eu_emergency_trust_fund_for_ africa_2I-03-20I8_-_us_letter_-_eu_logo.pdf (accessed I August 20I8)

Evans, Brad (2013) Liberal Terror, London and Cambridge, Polity.

Ferguson, James (2006). Global Shadows. Africa in the Neoliberal World Order. Durham and London, Duke University Press.

Galeano, Eduardo (1997). 'To Be Like Them' in Majid Rahnema \& Victoria Bawtree (eds)., The PostDevelopment Reader. London, Zed Books

Global Health Advocates (2018) 'The EU Emergency Trust Fund for Africa' available at http://www. ghadvocates.eu/wp-content/uploads/2017/og/Misplaced-Trust_FINAL-VERSION.pdf (accessed ro August 2018)

Global Witness (2015) Blood Timber. How Europe played a significant role in funding war in the Central African Republic July. Available at, https:||www.globalwitness.org/en-gb/campaigns/forests/bloodtimber/ (accessed 12 August 2018)

(2012) Rigged? The Scramble for Africa's Oil, Gas and Minerals. January Available at, http://www.globalwitness.org/sites/default/files/library/RIGGED\%20The\%20Scramble\%20 for\%20Africa's\%20oil,\%20gas\%20and\%2ominerals\%20.pdf (accessed 22 February 2013.

- (2009) The Secret Life of a Shopaholic. How an African Dictator's playboy son went ona multimillion dollar shopping spree in the US. A report by Global Witness November, available at https://www.globalwitness. org/sites/default/files/pdfs/gw_obiang_low.pdf (accessed I2 August 20I8) 
Graham, Yao (2015) 'The Africa Mining Vision and Mineral Governance in Africa: Struggles over discourses, policies and practices' presentation to University of Toronto, April

Greenspan, Emily, "Free, Prior, and Informed Consent in Africa: An emerging standard for extractive industry projects," Oxfam America Research Backgrounder series (20I4): [www.oxfamamerica. org/publications/fpic-in-africa].

Gruffydd Jones, Branwen (2008) 'The Global Political Economy of Social Crisis: Towards a Critique of the "Failed State" Ideology, Review of International Political Economy I5, no.2, I80-205

Gruffydd Jones, Branwen (2008) “"Tell no Lies, Claim no Easy Victories”. Possibilities and Contradications of Emancipatory Struggles in the Currrent Neo Colonial Condition' in Alison J. Ayers ed., Gramsci, Political Economy and International Relations Theories. Houndmills. Palgrave

Harrison, Graham (2010) Neoliberal Africa. The Impact of Global Social Engineering, London, Zed Books

Hentschel, Thomas, Felix Hruschka and Michael Priester (2003). Artisanal and Small Scale Mining: Challenges and Opportunities. London, IIED.

Hochschild, Adam (1998). King Leopold's Ghost, New York, Houghton Mifflin.

Ighobor, Kingsley (2017). 'Commodity prices crash hits Africa', Africa Renewal, December 2016-March 2017, 30-31

International Monetary Fund, (2016) Regional Economic Outlook. Sub Saharan Africa: time for a policy reset. World Economic and Financial Survey. Washington. IMF.

Jerven, Morten (2015) Africa. Why Economists Get it Wrong. London. Zed Books

Keenan, Jeremy (2009) The Dark Sahara. America's War on Terror in Africa London. Pluto Press

Kharas, Homi (20II) The Emerging Middle Class in Developing Countries. The Brookings Institute, June $\mathrm{xx}$ available at http://siteresources.worldbank.org/EXTABCDE/ Resources/7455676-I292528456380/762679I-I303I4I64I402/7878676-I306699356046/ParallelSesssion-6-Homi-Kharas.pdf (accessed I August 2018)

Klein, Naomi (2014) This Changes Everything, New York ., Simon \& Schuster

Lawrence, Peter (2018) 'Finance and development: what is to be done? In Review of African Political Economy vol 45, no. I56, June pp274-28I

Lawrence, Peter (2010) 'Development by numbers', New Left Review 62 March-April available at https://newleftreview.org/II/62/peter-lawrence-development-by-numbers (accessed II August 2018)

Laudati, Ann (2013) 'Beyond minerals: broadening 'economies of violence' in eastern Democratic Republic of Congo' in Review of African Political Economy 40, I35, pp32-50

Leys, Colin (1996) 'The Crisis in 'Development Theory' in New Political Economy, I, (I) pp4I-58

Marinovich, Greg, Sipho Hlongwane \& Thabo Lekwgowa, (2013). 'Marikana Massacre: Shocking new footage raises fresh questions' in Guardian Africa Network, Guardian.co.uk 29 January, http://www.guardian.co.uk/world/2013/jan/29/marikana-massacre-police-footage (accessed 22 February 2013).

Meager, Kate. (2003) 'A Back Door to Globalisation? Strucutral Adjustment, Globalisation \& Transborder Trade in West Africa' Review of African Political Economy vol30, 95, March, pp57-75

Melber, Henning (2017) 'Why the private sector's hype about the African Middle Class isn't helpful' The Conversation I November, available at https://theconversation.com/why-the-private-sectors-hypeabout-the-african-middle-class-isnt-helpful-85942 (accessed I August 2018)

Mhone, Guy, C.Z. (200I), 'Enclavity and Constrained Labour Absorptive Capacity in Southern African Economies' Paper for discussion at the UNRISD meeting on 'The Need to Rethink Development Economics' 7-8 September Cape Town, South Africa, available at; http://www.unrisd. org/80256B $3 \mathrm{Coo}_{5} \mathrm{BCCF}$ /httpNetITFramePDF?ReadForm\&parentunid=B81999299E53 $\mathrm{F}_{9} \mathrm{ECC}_{2} 25$ 6BC90047A 536\&parentdoctype $=$ paper\&netitpath $=80256 \mathrm{~B}_{3} \mathrm{Coo}_{5} \mathrm{BCCF} /($ httpAuxPages $) / \mathrm{B} 819992$ 99E53F9ECCr256BC90047A536/\$file/mhone.pdf 
Mine (2018) The digital magazine for the mining industry, Issue 7I, August, available at https://mine.nridigital.com/mine_augi8/issue_7I (accessed Io August 2018)

Mkandawire, Thandika (2014) 'Can Africa Turn from Recovery to Development?, Current History, May, ppI7I-I77

Mohan, Giles \& Ben Lampert (2012). 'Negotiating China: Reinserting African Agency into China-Africa Relations' in African Affairs, II2, (446) January, pp92-IIo

Moyo, Dambisa (2010) Dead Aid. Harmonsworth, Penquin

Moore, Jason, 2015, Capitalism in the Web of Life, London, Verso

Ndikumana, Léonce \& James K. Boyce (20II). Africa's Odious Debts. How Foreign Loans and Capital Flight Bled a Continent. London, Zed Books.

- (2012). 'Rich Presidents of Poor Nations: Capital Flight from Resource-Rich Countries in Africa' in Association of Concerned Africa Scholars, Bulletin, 87, Fall 2012, pp2-7

Nkrumah, Kwame (1976) Dark Days in Ghana London. Panaf.

Ochieng, George. M., Seanego, E.S., and O.I. Nkwonta, (2010) 'Impacts of mining on Water resources in South Africa: A Review', Scientific Ressearch and Essays,

Organisation of African Unity (I980) Lagos plan of action for the economic development of Africa 1980-2000 available at http://www.uneca.org/itca/ariportal/docs/lagos_plan.PDF (accessed 25 February 2013)

Organisation of Economic Cooperation and Development (2016) Development Aid at a Glance. Statistics by Region. Available at, https://www.oecd.org/dac/stats/documentupload/2\%20Africa\%20-\%20 Development\%20Aid\%20at\%20a\%20Glance\%202016.pdf (accessed I2 August 2018)

Owusu-Koranteng, Daniel and Hannah Owusu Koranteng(2017) 'The menace of mining and Water pollution, Ghana Web available at https://www.ghanaweb.com/GhanaHomePage/NewsArchive/ The-menace-of-mining-and-water-pollution- 526482 (accessed I4 August 2018)

Pambazuka: Voices for Freedom and Justice (2018) available at www.pambazuka.org

Review of African Political Economy (I974) 'Editorial' number I, Aug-Nov I974, reprinted June 1978

Review of African Political Economy (1976) no. 5

Reyntjens, F. (2009) The Great African Wat: Congo and Regional Geopolitics 1996-2006. Cambridge. Cambridge University Press.

Rosenburg, Justin (2006). 'Why is there no international historical sociology?' European Journal of International Relations, I2, 3, pp307-340

Sachs, Jeffrey (20II) The End of Poverty. Harmonsworth. Penquin.

Selwyn, Benjamin, (2017) The Struggle for Development. Cambridge. Polity

Selwyn, Benjamin, (2016) 'Global Value Chains and human development: a class-relational perspective', Third World Quarterly 37, ro, ppi768-86

Severino, Jean-Michel \& Olivier Ray, (20II) Africa's Moment. London and Cambridge Polity

Shivji, Issa. G. (2003) The Life and Times of Babu: The Age of Liberation \& Revolution, Review of African Political Economy vol30 95, ppro9-II8

Spronk, Susan \& Jeffery R. Webber, (2007) 'Struggles Against Accumulation by Dispossession in Bolivia. The Political Economy of Natural Resource Contention', Latin American Perspectives, March, $34, \mathrm{pp}_{3} \mathrm{I}-47$

Taylor, Ian (2016) 'Dependency redux: why Africa is not rising' Review of African Political Economy, $43,147,8-25$

The Economist , (2011) Africa Rising, 3 December

- (2000) Hopeless Continent I3 May

United Nations (20I0). Africa Fact Sheet. Main Economic Indicators. Office of the Special Advisor on Africa, (available at www.un.org/africa.osaa) 
United Nations Development Programme (n.d.) Understanding African Experiences in Formulating and implementating plans for Emergence. Growing Manufacturing Industrialisations in Ethiopia. Case Study. http://www.et.undp.org/content/dam/ethiopia/docs/Understanding\%2oAfrican\%20 experiences\%2oin \%2oformulating\%2oand\%2oimplementing\%2oplans $\% 20$ for $\% 20$ emergence\%20Growing\%20Manufacturing\%2oIndustry.pdf

United Nations Economic Commission for Africa (2018) Scaling up value creation and local development in the (upstream) mining sector in Ghana', forthcoming, will be available from www.eca.org

United Nations Economic Commission for Africa (2017) African Mining Vision: African Minerals Governance Framework. Addis Ababa. ECA

United Nationas Economic Commission on Africa (2012). Unleashing Africa's Potential as a Pole of Global Growth, Addis Ababa, Economic Commission for Africa and Africa Union.

- (2012a). 'Report blames multinationals for illicitly transferring most of the \$I.5 trillion made in Africa each year' ECA Press Release I29/20I2 (available from www.uneca.org)

United Nations Economic Commission for Africa (20I5) Millennium Development Goals Report 2015 Assessing Progress in Africa Towards the MDG's https://www.uneca.org/publications/mdg-report-2015assessing-progress-africa-toward-millennium-development-goals (accessed I5 January 20I8).

United Nations Conference on Trade and Development (2017) World Investment Report 2017. Geneva, UNCTAD.

- (2016) Economic Development in Africa. Report 2016. Debt Dynamics \& Development Finance Geneva, UNCTAD http://unctad.org/en/PublicationsLibrary/aldcafrica2or6_en.pdf (accessed ıo January 20I8)

(2012). Economic Development in Africa Report 2012 Structural Transformation and Sustainable Development in Africa (available at http://unctad.org/en/PublicationsLibrary/aldcafrica20I2_embargo_en.pdf)

United Nations Industrial Development Organisation, (20I6). Industrialization in Africa and Least Developed Countries. Boosting growth, creating jobs, promoting inclusiveness and sustainability. A Report to the G20 Development Working Group by UNIDO. https://www.unido.org/sites/default/files/20I6-og/ UNIDO_20I6_G20_08_25_0.pdf (accessed I5 January 2018)

Veltmeyer, Henry. (2016) 'Extractive Capital, the Stte and the Resistance in Latin America' Sociology and Anthropology vol48, pp774-784

Vlassenroot, K and C Huggins, (2005) Land, Migration and conflict in C Huggins and J Glover eds., From the Ground Up: land rights, conflict and peace in sub-Saharan Africa. Pretoria. ISS,ppII5-I94

Withall, Adam (20I6), 'Is the entire GDP of Africa really just equal to that of France' I8 October available at, http://www.independent.co.uk/news/world/africa/is-the-entire-gdp-of-africa-reallyjust-equal-to-that-of-france-a7367906.html (accessed 8 January 20I8)

World Bank (20I7) The World Bank in Africa, II, October. http://www.worldbank.org/en/region/afr/ overview (accessed 9 January 20I8)

World Bank (2015). Ethiopia Economic Update: A Flourishing Manufaacturing Industry Will help more Ethiopians. July. Avaialable at http://www.worldbank.org/en/country/ethiopia/publication/fourth-ethiopiaeconomic-update-overcoming-contraints-manufacturing-sector (accessed 2 August 2018)

(20II) World Development Report 2011: Conflict, Security and Development. Washington DC., World Bank. (2000). Can Africa Claim the 21st Century? Washington, World Bank

Young, Tom (2010), Africa. Oxford, Oneworld 